\title{
Chryseobacterium treverense sp. nov., isolated from a human clinical source
}

\author{
Correspondence \\ A. F. Yassin \\ yassin@mibiO3.meb.uni-bonn.de
}

\author{
A. F. Yassin, ${ }^{1}$ H. Hupfer, ${ }^{2}$ C. Siering ${ }^{2}$ and H.-J. Busse ${ }^{3}$ \\ ${ }^{1}$ Institut für Medizinische Mikrobiologie und Immunologie der Universität Bonn, \\ Sigmund-Freud-Straße 25, 53127 Bonn, Germany \\ ${ }^{2}$ Kekulé-Institut für Organische Chemie und Biochemie der Universität Bonn, 53121 Bonn, \\ Germany \\ ${ }^{3}$ Institut für Bakteriologie, Mykologie und Hygiene, Veterinärmedizinische Universität Wien, \\ A-1210 Wien, Austria
}

\begin{abstract}
A yellow-pigmented, Gram-reaction-negative bacterium isolated from a human clinical source was investigated using a polyphasic approach in order to clarify its taxonomic status. Comparative $16 \mathrm{~S}$ rRNA gene sequence analysis showed that the new isolate constituted a distinct phyletic line within the genus Chryseobacterium, displaying $>2.8 \%$ sequence divergence with recognized species of this genus. The generic assignment was confirmed by chemotaxonomic data which revealed a fatty acid profile consisting of straight-chain saturated, monounsaturated and branched-chain fatty acids of iso-/anteiso-types as well as 3-hydroxylated fatty acids; a menaquinone with six isoprene units (MK-6) as the predominant respiratory quinone and sym-homospermidine as the predominant polyamine. The novel isolate could be distinguished from other members of the genus Chryseobacterium by a set of distinct biochemical properties. On the basis of phenotypic and phylogenetic evidence, it is proposed that the new isolate represents a novel species of the genus Chryseobacterium for which the name Chryseobacterium treverense sp. nov. is proposed. The type strain is IMMIB L-1519 $\left(=\mathrm{DSM} 22251^{\top}=\right.$ CCUG $\left.57657^{\top}\right)$.
\end{abstract}

The genus Chryseobacterium Vandamme et al. 1994 emend. Kämpfer et al. 2009 was originally proposed to comprise the generically misclassified organisms Flavobacterium balustinum, Flavobacterium gleum, Flavobacterium indologenes, Flavobacterium indoltheticum, Flavobacterium meningosepticum and Flavobacterium scophthalmum with Chryseobacterium gleum as the type species. Members of the genus Chryseobacterium are aerobic, catalase- and oxidase-positive, chemo-organotrophic, non-motile, non-spore-forming, Gram-reaction-negative and rod-shaped bacteria. These include typically pigmented (yellow to orange) species as well as non-pigmented ones. Members of the genus can be characterized chemotaxonomically by having a fatty acid profile that contains iso-, anteiso- and 3-hydroxy fatty acids (Segers et al., 1993; Vandamme et al., 1994; Kämpfer et al., 2009 b). They contain menaquinone MK-6 as the only respiratory quinone and sym-homospermidine as the major polyamine. The number of recognized species of the genus Chryseobacterium has increased rapidly. Some of the newly described species have resulted from the taxonomic revision of existing genera, e.g. Kaistella and Sejongia (Kämpfer et al.,

The GenBank/EMBL/DDBJ accession number for the 16S rRNA gene sequence of strain IMMIB L-1519 ${ }^{\top}$ is FN297836.

A figure showing the TLC of the polar lipids of strain IMMIB L-1519 is available as supplementary material with the online version of this paper. 2009a, b). At the time of writing, the genus Chryseobacterium comprises 42 recognized species (http://www.bacterio.cict. $\mathrm{fr} /$ ). These include species isolated from a variety of environmental sources, e.g. soil, water, sludge, plants, food products such as fish, meat, poultry, milk and lactic acid beverages, and human clinical specimens (Bernardet et al., 2005, 2006; Quan et al., 2007; Vaneechoutte et al., 2007). During the course of characterization of bacterial isolates encountered from clinical sources, a polyphasic approach was used to characterize a Gram-reaction-negative, yellowpigmented, rod-shaped bacterium. Based on the results of this study, we describe a novel species of the genus Chryseobacterium.

Strain IMMIB L-1519 ${ }^{\mathrm{T}}$ was isolated from an aerobic BACTEC bottle (BD) inoculated with a blood sample from an apparently healthy man in Trier, Germany. The strain was grown aerobically at $37{ }^{\circ} \mathrm{C}$ on Columbia agar (Oxoid) supplemented with $5 \%$ sheep blood and preserved in fetal calf serum by lyophilization. Anaerobic growth was investigated using incubation in the GasPak anaerobic system (BBL) for 15 days at $27^{\circ} \mathrm{C}$ on Columbia agar. Chryseobacterium jeonii DSM $17048^{\mathrm{T}}$ and Chryseobacterium anthropi NF $1366^{\mathrm{T}}$ were used as reference strains. The three strains were characterized biochemically using the API 20E, API 20NE, API 50CH and API ZYM identification systems 
according to the manufacturer's instructions (bioMérieux). Growth was tested on cetrimide agar and MacConkey agar (Oxoid). Growth temperature (tested at 5, 10, 22, 30, 37 and $42{ }^{\circ} \mathrm{C}$ ) was determined on Columbia agar supplemented with $5 \%$ sheep blood. Tolerance of $\mathrm{NaCl}(0,0.5,1.5,3,6,8$ and $10 \% ; \mathrm{w} / \mathrm{v}$ ) was determined in nutrient broth. Motility was observed by the hanging drop technique for cells in the exponential phase in nutrient broth. The $\mathrm{KOH}$ test was used to detect flexirubin pigments (Bernardet et al., 2002). Oxidase was determined using two different methods: the conventional method based on using $N, N, N^{\prime}, N^{\prime}$-tetramethyl-p-phenylenediamine (Smibert \& Krieg, 1994) and the alternative method based on the DrySlide Oxidase Test (BD BBL System). The presence of catalase was assessed using $3 \%(\mathrm{v} / \mathrm{v}) \mathrm{H}_{2} \mathrm{O}_{2}$. DNase test agar (Difco) was used for the DNase assay. Citrate utilization was tested on Simmons' citrate agar. Indole production was determined with Kovács' indole reagent in $1 \%$ tryptone broth. $\mathrm{H}_{2} \mathrm{~S}$ production was determined on Kligler's iron agar. Hydrolysis of starch was examined on nutrient agar containing $0.2 \%$ soluble starch (Barrow \& Feltham, 1993). Hippurate hydrolysis was determined according to the method of Hwang \& Ederer (1975). Tween 80 hydrolysis was detected using Tween 80 medium according to the method of Sierra (1957). Hydrolysis of adenine, casein, elastin, guanine, xanthine, hypoxanthine, testosterone and tyrosine was investigated by using previously described methods (Gordon, 1966, 1967; Gordon \& Mihm, 1957). For chemotaxonomic studies, the three strains were cultivated in shake flasks containing BHI broth (BD) for 1 week at $22{ }^{\circ} \mathrm{C}$. After checking for purity at maximum growth, the organisms were killed with formaldehyde $(1 \%, v / v)$, harvested by centrifugation, washed with distilled water and freeze-dried. Standard procedures were used to determine the fatty acid profile (Minnikin et al.,1980; Yassin et al., 2007), phospholipid composition (Yassin et al., 1993) and isoprenoid quinones (Collins et al., 1977; Yassin \& Hupfer, 2006). The biomass of strain IMMIB $\mathrm{L}-1915^{\mathrm{T}}$ used for polyamine analysis was grown on PYE medium $(0.3 \%$ peptone from casein, $0.3 \%$ yeast extract, $\mathrm{pH}$ 7.2), harvested at the late exponential growth phase and lyophilized. Extraction of polyamines was performed as described by Busse \& Auling (1988) and analysis was conducted using the HPLC equipment described by Stolz et al. (2007).

For phylogenetic analysis, the 16S rRNA gene of strain IMMIB L- $1519^{\mathrm{T}}$ was amplified by PCR using the procedure of Rainey et al. (1996) then directly sequenced using a Taq dye-deoxy terminator cycle sequencing kit (Applied Biosystems) and an automatic DNA sequencer (model 310; Applied Biosystems). The closest relatives of the new isolate were determined by performing BLAST database searches. The $16 \mathrm{~S}$ rRNA gene sequence of isolate IMMIB L$1519^{\mathrm{T}}$, as well as closely related sequences retrieved from GenBank, were added to the ARB database (Ludwig et al., 2004) and aligned using the appropriate tool from the ARB package. Phylogenetic trees were reconstructed according to the neighbour-joining (Saitou \& Nei, 1987), maximum- parsimony (Fitch, 1971) and maximum-likelihood (Felsenstein, 1981) methods. The stability of the groupings was estimated by bootstrap analysis (Felsenstein, 1985) of the neighbour-joining method based on 1000 replications.

To establish the phylogenetic position of strain IMMIB $\mathrm{L}-1519^{\mathrm{T}}$, its $16 \mathrm{~S}$ rRNA gene sequence was determined in this study (1523 nt). Sequence database searches revealed that strain IMMIB L- $1519^{\mathrm{T}}$ was most closely related to species of the genus Chryseobacterium (data not shown). Phylogenetic analysis confirmed the association of strain IMMIB L- $1519^{\mathrm{T}}$ with the genus Chryseobacterium. A tree constructed using the neighbour-joining method showing the phylogenetic position of strain IMMIB L-1519 ${ }^{\mathrm{T}}$ is shown in Fig. 1. It is evident from the tree that strain IMMIB L- $1519^{\mathrm{T}}$ represents a hitherto unknown subline that clusters with Chryseobacterium antarcticum, Chryseobacterium jeonii and Chryseobacterium marinum, although bootstrap resampling analysis showed that this association was not particularly significant. Comparative $16 \mathrm{~S}$ rRNA gene sequence analysis demonstrated that strain IMMIB L- $1519^{\mathrm{T}}$ displayed sequence similarity values of less than $97.2 \%$ to the type strains of recognized species of the genus Chryseobacterium. The highest sequence similarity was shown with C. jeonii JCM $12382^{\mathrm{T}}(97.2 \%)$, C. anthropi NF $1366^{\mathrm{T}}(96.7 \%)$ and Chryseobacterium haifense DSM $19056^{\mathrm{T}}$ (96.6\%). Other species of the genus Chryseobacterium displayed substantially lower levels of similarity (data not shown). Although it is not possible to delineate species solely on the basis of 16S rRNA gene sequence similarities, it is clear that the observed $\geqslant 2.8 \%$ divergence between the unidentified organism and the currently recognized species of the genus Chryseobacterium is consistent with separate species status. It is now recognized that the genus Chryseobacterium contains a number of species that share 16S rRNA gene sequence similarities of significantly higher than $97 \%$ while showing DNA-DNA relatedness values well below the $70 \%$ cut-off point recommended by Wayne et al. (1987) for the delineation of genomic species. For instance, Chryseobacterium daecheongense and Chryseobacterium defluvii share $97.9 \%$ 16S rRNA gene sequence similarity while their genomic DNA exhibits only $33.9 \%$ relatedness (Kim et al., 2005). Similarly, the 16S rRNA gene sequence of Chryseobacterium aquifrigidense is $98.4 \%$ and $97.8 \%$ similar to those of Chryseobacterium gleum and Chryseobacterium indologenes, respectively, but the corresponding DNA-DNA relatedness values are $39 \%$ and $17 \%$ (Park et al., 2008). A similar situation has also been reported for the following pairs of type strains: C. ureilyticum/C. joostei (Herzog et al., 2008), C. luteum/C. shigense (Behrendt et al., 2007) and C. piscium/C. balustinum and C. scophthalmum (de Beer et al., 2006). Thus the $97.2 \% 16$ S rRNA gene sequence similarity value between strain IMMIB L-1519 ${ }^{\mathrm{T}}$ and its closest neighbour C. jeonii JCM $12382^{\mathrm{T}}$ demonstrates that they belong to different genospecies (Stackebrandt \& Ebers, 2006). We therefore did not determine the level of DNADNA relatedness between the two strains. Moreover, the distinctive phenotype of strain IMMIB L- $1519^{\mathrm{T}}$ (Table 1) confirmed that it represents a novel species. 


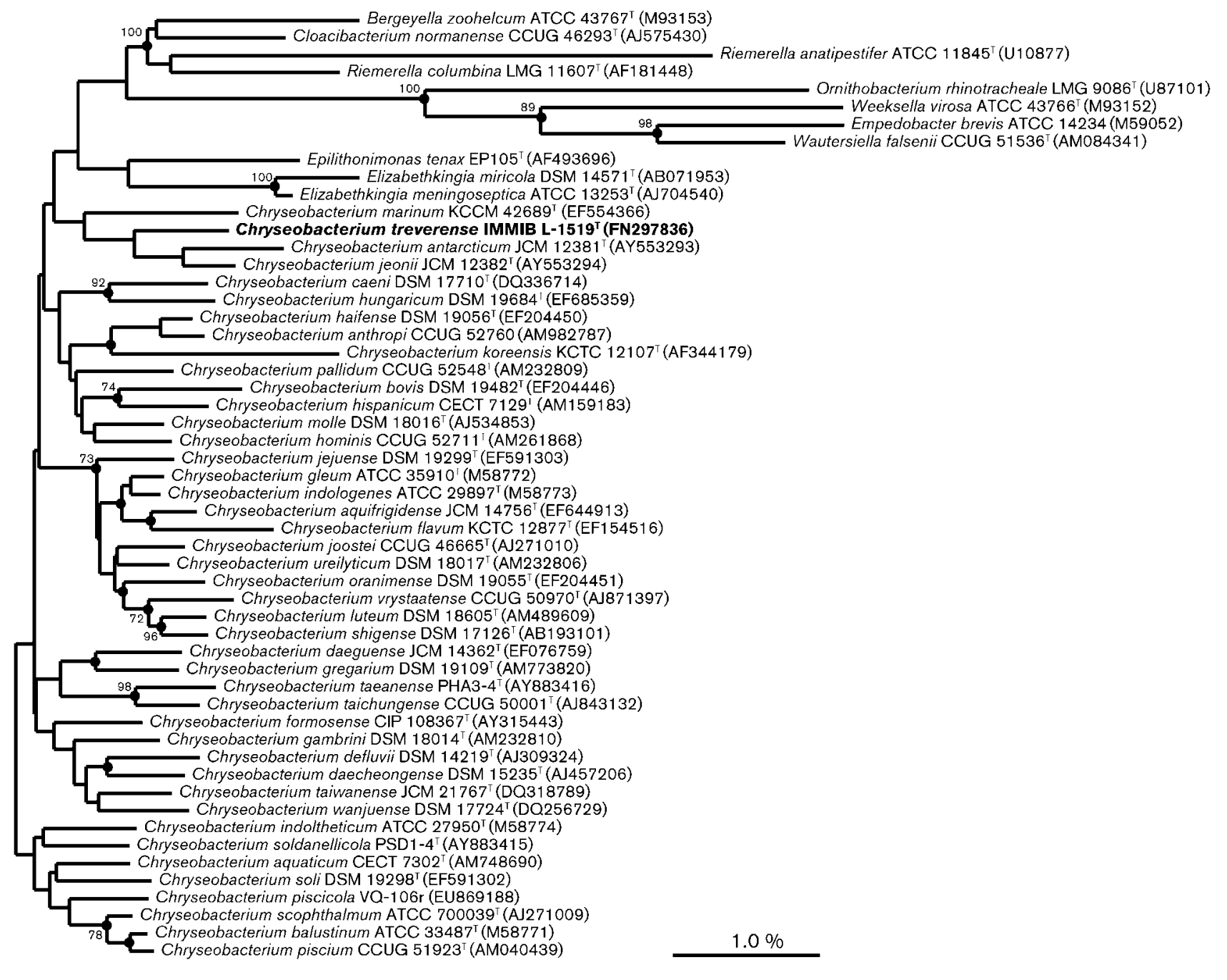

Fig. 1. Neighbour-joining phylogenetic tree based on 16S rRNA gene sequences showing the position of strain IMMIB $\mathrm{L}-1519^{\top}$ within the radiation of species of the genus Chryseobacterium. The numbers at the nodes indicate the level of bootstrap support $>70 \%$ based on neighbour-joining analyses of 1000 resampled datasets; solid circles indicate that the corresponding nodes (groupings) were also recovered in the maximum-likelihood and maximum-parsimony trees. Bar, $1.0 \%$ sequence divergence. The tree was rooted using Bergeyella zoohelcum ATCC $43767^{\top}$ as an outgroup.

Strain IMMIB L-1519 ${ }^{\mathrm{T}}$ exhibited chemical markers characteristic for the genus Chryseobacterium. Cellular fatty acid analysis (Table 2) revealed the presence of saturated and monounsaturated fatty acid with straight-chain, iso-/ anteiso-branched-chain and 3-OH fatty acids. The predominant fatty acids were $\mathrm{C}_{15: 0}$ anteiso $(65.3 \%), \mathrm{C}_{15: 0}$ iso $(16.8 \%)$ and $\mathrm{C}_{17: 0}$ anteiso 3-OH $(55.9 \%)$. The new isolate could be distinguished from its two closest phylogenetic neighbours by clear differences in the proportions of $\mathrm{C}_{15: 0}$ iso, $\mathrm{C}_{17: 0}$ iso $3-\mathrm{OH}$ and $\mathrm{C}_{17: 0}$ anteiso 3-OH. Strain IMMIB $\mathrm{L}-1519^{\mathrm{T}}$ contained phosphatidylethanolamine as the only identified phospholipid. Mass spectral analysis of the main isoprenoid quinone isolated from strain IMMIB L-1519 showed a strong peak at $\mathrm{m} / z 581.37$ attributable to $[\mathrm{M}+\mathrm{H}]^{+}$in the high mass region. This corresponds to a menaquinone with six unsaturated isoprene units (MK-6).
The polyamine pattern of strain IMMIB L- $1519^{\mathrm{T}}$ consisted of the predominant compound sym-homospermidine (17.4 $\mu \mathrm{mol} \mathrm{g}^{-1}$ dry weight), spermidine $\left(3.5 \mu \mathrm{mol} \mathrm{g}^{-1}\right.$ dry weight), spermine $\left(1.4 \mu \mathrm{mol} \mathrm{g}^{-1}\right.$ dry weight $)$ and traces of putrescine $\left(<0.1 \mu \mathrm{mol} \mathrm{g}^{-1}\right.$ dry weight). The results of the chemotaxonomic studies and the polyamine pattern were in excellent agreement with those of other species of the genus Chryseobacterium (Kämpfer et al., 2009b).

Strain IMMIB L- $1519^{\mathrm{T}}$ could be distinguished from its phylogenetic neighbours C. jeonii DSM $17048^{\mathrm{T}}$ and $C$. anthropi NF $1366^{\mathrm{T}}$ by its ability to grow in the presence of $6 \% \mathrm{NaCl}$, to produce flexirubin type pigments, to assimilate adipate and to hydrolyse starch (in 2 days) and by its inability to hydrolyse DNA, hippurate and Tween 80 (Table 1). Using two different methods, the oxidase reaction 
Table 1. Differentiating phenotypic characteristics of strain IMMIB L-1519 ${ }^{\top}$ and closely related species of the genus Chryseobacterium

Strains: 1, IMMIB L- $1519^{\mathrm{T}}$; 2, C. jeonii DSM $17048^{\mathrm{T}} ; 3$, C. anthropi NF $1366^{\mathrm{T}}$. All data are from this study. All strains are positive for: growth at 5, 10 and $22{ }^{\circ} \mathrm{C}$; assimilation of D-glucose and malate; hydrolysis of casein and tyrosine; and catalase, acid phosphatase, alkaline phosphatase, leucine arylamidase, valine arylamidase and naphthol-AS-BIphosphohydrolase activities. All strains are negative for: growth at $42{ }^{\circ} \mathrm{C}$ and on MacConkey and cetrimide agars; production of indole, acetoin, $\mathrm{H}_{2} \mathrm{~S}$ and L-phenylalanine deaminase; citrate alkalinization; assimilation of L-arabinose, capric acid and D-mannitol; hydrolysis of elastin, guanine, hypoxanthine, testosterone and xanthine; and $\alpha$ chymotrypsin, cystine arylamidase, esterase C4, ester lipase C8, lecithinase, lipase $\mathrm{C} 14, \beta$-galactosidase, nitrate reductase and urease activities. + , Positive; - , negative; $\mathrm{w}$, weakly positive.

\begin{tabular}{|lccc|}
\hline Characteristic & $\mathbf{1}$ & $\mathbf{2}$ & $\mathbf{3}$ \\
\hline Assimilation of: & & & \\
N-Acetylglucosamine & + & + & - \\
Adipate & + & - & - \\
Citrate & + & + & - \\
Gluconate & + & + & - \\
D-Mannose & + & - & + \\
Phenylacetic acid & + & + & - \\
Growth at: & & & \\
$30{ }^{\circ} \mathrm{C}$ & + & - & + \\
$37{ }^{\circ} \mathrm{C}$ & $+*$ & - & + \\
Growth with $6 \%$ NaCl & + & - & - \\
Hydrolysis of & & & \\
Adenine $(21$ days $)$ & - & + & - \\
Hippurate & - & + & + \\
DNA (3 days) & - & $\mathrm{w}$ & + \\
Starch $(3$ days $)$ & + & - & - \\
Tween $80(16$ days $)$ & - & + & + \\
Oxidase activity & + & $-(+) \dagger$ & + \\
Production of flexirubin pigments & + & - & - \\
& & & \\
\hline
\end{tabular}

${ }^{\star}$ The strain lost its viability after 4 days of incubation at this temperature.

$\dagger$ Data from Yi et al. (2005).

of C. jeonii DSM $17048^{\mathrm{T}}$ was negative in our hands, although a positive reaction was originally reported by Yi et al. (2005). The detailed phenotypic characteristics of strain IMMIB $\mathrm{L}-1519^{\mathrm{T}}$ are given in the species description and in Table 1 .

Therefore, based on both phenotypic and molecular-genetic considerations, we consider that strain IMMIB L-1519 ${ }^{\mathrm{T}}$ represents a novel species of the genus Chryseobacterium, for which the name Chryseobacterium treverense sp. nov. is proposed.

\section{Description of Chryseobacterium treverense sp. nov.}

Chryseobacterium treverense [tre.ve.ren'se. L. neut. adj. treverense pertaining to Augusta Trevirorum, the Latin
Table 2. Cellular fatty acid composition (\%) of strain IMMIB $\mathrm{L}-1519^{\top}$ and the most closely related species of the genus Chryseobacterium

Strains: 1, IMMIB L-1519 ${ }^{\mathrm{T}} ; 2$, C. jeonii DSM $17048^{\mathrm{T}} ; 3$, C. anthropi $\mathrm{NF} 1366^{\mathrm{T}}$. All data from this study. Fatty acids amounting to $<0.5 \%$ of the total fatty acids are not shown. tr, traces $(<0.5 \%)$; ND, not detected. Values do not add up to $100 \%$ as the hydroxylated and nonhydroxylated fatty acids were firstly separated by TLC and then analysed separately with GC-MS (see text for further details).

\begin{tabular}{|c|c|c|c|}
\hline Fatty acid & 1 & 2 & 3 \\
\hline \multicolumn{4}{|l|}{ Saturated } \\
\hline $\mathrm{C}_{14: 0}$ & $\operatorname{tr}$ & $\operatorname{tr}$ & 0.7 \\
\hline $\mathrm{C}_{16: 0}$ & $\operatorname{tr}$ & 0.8 & 1.6 \\
\hline $\mathrm{C}_{18: 0}$ & $\mathrm{ND}$ & $\operatorname{tr}$ & 1.0 \\
\hline \multicolumn{4}{|l|}{ Unsaturated } \\
\hline $\mathrm{C}_{16: 1} \omega 5 c$ & $\mathrm{ND}$ & 2.8 & 0.6 \\
\hline $\mathrm{C}_{16: 1} \omega 7 c$ & $\operatorname{tr}$ & 0.7 & 0.6 \\
\hline $\mathrm{C}_{18: 1} \omega 5 c$ & $\mathrm{ND}$ & 1.3 & 0.5 \\
\hline \multicolumn{4}{|l|}{ Branched-chain } \\
\hline $\mathrm{C}_{13: 0}$ iso & ND & 3.1 & 1.8 \\
\hline $\mathrm{C}_{13: 0}$ anteiso & $\operatorname{tr}$ & 3.0 & $\operatorname{tr}$ \\
\hline $\mathrm{C}_{14: 0}$ iso & $\mathrm{ND}$ & 0.5 & ND \\
\hline $\mathrm{C}_{15: 0}$ iso & 16.8 & 24.8 & $\mathrm{ND}$ \\
\hline $\mathrm{C}_{15: 0}$ anteiso & 65.3 & 50.4 & 59.7 \\
\hline $\mathrm{C}_{16: 1}$ iso $\omega 7 c$ & $\operatorname{tr}$ & 0.7 & ND \\
\hline $\mathrm{C}_{16: 0}$ iso & 1.7 & $\operatorname{tr}$ & 3.4 \\
\hline $\mathrm{C}_{17: 1}$ iso $\omega 9 c$ & 8.6 & 8.6 & 13.3 \\
\hline $\mathrm{C}_{17: 0}$ iso & 0.8 & ND & 8.3 \\
\hline $\mathrm{C}_{17: 0}$ anteiso & 2.6 & $\operatorname{tr}$ & 4.5 \\
\hline \multicolumn{4}{|l|}{ Hydroxy } \\
\hline $\mathrm{C}_{13: 0}$ iso $3-\mathrm{OH}$ & 0.7 & 4.8 & 5.3 \\
\hline $\mathrm{C}_{13: 0}$ anteiso $3-\mathrm{OH}$ & 4.1 & 9.5 & 6.0 \\
\hline $\mathrm{C}_{15: 0}$ iso $3-\mathrm{OH}$ & 4.5 & 9.1 & 1.4 \\
\hline $\mathrm{C}_{15: 0}$ anteiso $3-\mathrm{OH}$ & 0.6 & 2.8 & $\operatorname{tr}$ \\
\hline $\mathrm{C}_{17: 0}$ iso $3-\mathrm{OH}$ & 31.6 & 34.3 & 73.2 \\
\hline $\mathrm{C}_{17: 0}$ anteiso $3-\mathrm{OH}$ & 55.9 & 22.6 & 13.9 \\
\hline
\end{tabular}

name of Treves (Trier, West Germany), the city from which the strain was sent for identification].

Cells are approximately $1.4-2.7 \times 0.5-0.6 \mu \mathrm{m}$. Gram-reaction-negative, non-spore-forming, non-motile, strictly aerobic, oxidase- and catalase-positive rods. Grows at $5-30{ }^{\circ} \mathrm{C}$ (optimum, $20{ }^{\circ} \mathrm{C}$ ). Growth also occurs at $37^{\circ} \mathrm{C}$ but the organism loses its viability after 4 days of incubation. No growth on MacConkey agar, cetrimide agar or with $8 \% \mathrm{NaCl}$. On Columbia agar, colonies are yellow-pigmented, mucous, circular with regular edges and smooth with a diameter of 2 $3 \mathrm{~mm}$. Grows on BHI agar and nutrient agar. Tolerates $0-6 \%$ $(\mathrm{w} / \mathrm{v}) \mathrm{NaCl}$ with optimum growth at $6 \% \mathrm{NaCl}$. Flexirubin pigments are produced. $\mathrm{N}$-Acetylglucosamine, adipate, Darabitol, L-arabitol, dulcitol, erythritol, D-fucose, glycogen, potassium gluconate, potassium 2-ketogluconate, potassium 5-ketogluconate, D-lyxose, D-tagatose, and turanose are assimilated. D-Adonitol, amygdalin, D-arabinose, L-arabinose, arbutin, capric acid, cellobiose, trisodium citrate, gentiobiose, 
D-galactose, potassium gluconate, D-glucose, glycerol, Dfructose, inositol, inulin, D-lactose, D-mannose, D-mannitol, maltose, malate, melezitose, melibiose, phenylacetate, raffinose, L-rhamnose, D-ribose, salicin, D-sorbitol, L-sorbose, sucrose, trehalose, xylitol, D-xylose and L-xylose are not assimilated. Acid is not produced from L-arabinose, glycogen, D-glucose, inulin, D-lactose, maltose, D-mannitol, raffinose, D-ribose, D-sorbitol, starch, sucrose, trehalose or D-xylose. Aesculin and casein are hydrolysed. Tyrosine is weakly hydrolysed after 3 weeks of incubation. Adenine, elastin, gelatin, guanine, hippurate, hypoxanthine, testosterone and xanthine are not hydrolysed. Activity is detected for acid phosphatase, alkaline phosphatase, ester lipase $\mathrm{C} 8$, leucine arylamidase, valine arylamidase, naphthol-AS-BI-phosphohydrolase and $\alpha$-glucosidase. No activity is detected for arginine dihydrolase, $\alpha$-chymotrypsin, cystine arylamidase, esterase $\mathrm{C} 4, \alpha$-fucosidase, $\alpha$-galactosidase, $\beta$-galactosidase, $\beta$ glucuronidase, $\beta$-glucosidase, $N$-acetyl- $\beta$-glucosaminidase, lipase C14, $\alpha$-mannosidase, trypsin or urease. Nitrate is not reduced. Tests for indole, acetoin, $\mathrm{H}_{2} \mathrm{~S}$, lecithinase and L-phenylalanine deaminase production are negative. Menaquinone MK-6 is the major isoprenoid quinone. The polyamine pattern consists of the major compound symhomospermidine, minor amounts of spermidine and spermine and traces of putrescine. The only identified phospholipid is phosphatidylethanolamine. The fatty acids $\mathrm{C}_{15: 0}$ anteiso, $\mathrm{C}_{15: 0}$ iso and $\mathrm{C}_{17: 1}$ iso $\omega 9 \mathrm{c}$ are the major nonhydroxylated fatty acids and $\mathrm{C}_{17: 0}$ iso $3-\mathrm{OH}$ and $\mathrm{C}_{17: 0}$ anteiso $3-\mathrm{OH}$ are the major hydroxylated fatty acids.

The type strain, IMMIB L- $1519^{\mathrm{T}}\left(=\mathrm{DSM} 22251^{\mathrm{T}}=\mathrm{CCUG}\right.$ $57657^{\mathrm{T}}$ ), was isolated from human blood in Trier, Germany.

\section{Acknowledgements}

We thank Professor Dr Hans-Georg Trüper for his nomenclatural advice.

\section{References}

Barrow, G. I. \& Feltham, R. K. A. (1993). Cowan and Steel's Manual for the Identification of Medical Bacteria, 3rd edn. Cambridge: Cambridge University Press.

Behrendt, U., Ulrich, A., Spröer, C. \& Schumann, P. (2007). Chryseobacterium luteum sp. nov., associated with the phyllosphere of grasses. Int J Syst Evol Microbiol 57, 1881-1885.

Bernardet, J.-F., Nakagawa, Y. \& Holmes, B. (2002). Proposed minimal standards for describing new taxa of the family Flavobacteriaceae and emended description of the family. Int J Syst Evol Microbiol 52, 10491070 .

Bernardet, J.-F., Vancanneyt, M., Matte-Tailliez, O., Grisez, L., Tailliez, P., Bizet, C., Nowakowski, M., Kerouault, B. \& Swings, J. (2005). Polyphasic study of Chryseobacterium strains isolated from diseased aquatic animals. Syst Appl Microbiol 28, 640-660.

Bernardet, J.-F., Hugo, C. \& Bruun, B. (2006). The genera Chryseobacterium and Elizabethkingia. In The Prokaryotes: a Handbook on the Biology of Bacteria, 3rd edn, vol. 7, pp. 638-676. Edited by M. Dworkin, S. Falkow, E. Rosenberg, K. H. Schleifer \& E. Stackebrandt. New York: Springer.
Busse, H.-J. \& Auling, G. (1988). Polyamine pattern as a chemotaxonomic marker within the Proteobacteria. Syst Appl Microbiol 11, 1-8.

Collins, M. D., Pirouz, T., Goodfellow, M. \& Minnikin, D. E. (1977). Distribution of menaquinones in actinomycetes and corynebacteria. J Gen Microbiol 100, 221-230.

de Beer, H., Hugo, C. J., Jooste, P. J., Vancanneyt, M., Coenye, T. \& Vandamme, P. (2006). Chryseobacterium piscium sp. nov., isolated from fish of the South Atlantic Ocean off South Africa Int J Syst Evol Microbiol 56, 1317-1322.

Felsenstein, J. (1981). Evolutionary trees from DNA sequences: a maximum likelihood approach. $J$ Mol Evol 17, 368-376.

Felsenstein, J. (1985). Confidence limits on phylogenies: an approach using the bootstrap. Evolution 39, 783-791.

Fitch, W. M. (1971). Toward defining the course of evolution: minimum change for a specific tree topology. Syst Zool 20, 406-416.

Gordon, R. E. (1966). Some criteria for the recognition of Nocardia madurae (Vincent) Blanchard. J Gen Microbiol 45, 355-364.

Gordon, R. E. (1967). The taxonomy of soil bacteria. In The Ecology of Soil Bacteria, pp. 293-321. Edited by T. R. G. Gray \& B. Parkinson. Liverpool: University Press.

Gordon, R. E. \& Minm, J. M. (1957). A comparative study of some strains received as nocardiae. J Bacteriol 73, 15-27.

Herzog, P., Winkler, I., Wolking, D., Kämpfer, P. \& Lipski, A. (2008). Chryseobacterium ureilyticum sp. nov., Chryseobacterium gambrini sp. nov., Chryseobacterium pallidum sp. nov. and Chryseobacterium molle sp. nov., isolated from beer-bottling plants. Int J Syst Evol Microbiol 58, 26-33.

Hwang, M.-N. \& Ederer, G. M. (1975). Rapid hippurate hydrolysis method for presumptive identification of Group B streptococci. J Clin Microbiol 1, 114-115.

Kämpfer, P., Lodders, N., Vaneechoutte, M. \& Wauters, G. (2009a). Transfer of Sejongia antarctica, Sejongia jeonii and Sejongia marina to the genus Chryseobacterium as Chryseobacterium antarcticum comb. nov., Chryseobacterium jeonii comb. nov., and Chryseobacterium marinum comb. nov. Int J Syst Evol Microbiol 59, 2238-2240.

Kämpfer, P., Vaneechoutte, M., Lodders, N., De Baere, T., Avesani, V., Janssens, M., Busse, H.-J. \& Wauters, G. (2009b). Description of Chryseobacterium anthropi sp. nov., to accommodate clinical isolates biochemically similar to Kaistella koreensis and Chryseobacterium haifense, proposal to reclassify Kaistella koreensis as Chryseobacterium koreense comb. nov. and emended description of the genus Chryseobacterium. Int J Syst Evol Microbiol 59, 2421-2428.

Kim, K. K., Bae, H. S., Schumann, P. \& Lee, S. T. (2005). Chryseobacterium daecheongense sp. nov., isolated from freshwater lake sediment. Int J Syst Evol Microbiol 55, 133-138.

Ludwig, W., Strunk, O., Westram, R., Richter, L., Meier, H., Yadhukumar, Buchner, A., Lai, T., Steppi, S. \& other authors (2004). ARB: a software environment for sequence data. Nucleic Acids Res 32, 1363-1371.

Minnikin, D. E., Hutchinson, I. G., Caldicott, A. B. \& Goodfellow, M. (1980). Thin-layer chromatography of methanolysates of mycolic acid-containing bacteria. J Chromatogr A 188, 221-223.

Park, S. C., Kim, M. S., Baik, K. S., Kim, E. M., Rhee, M. S. \& Seong, C. N. (2008). Chryseobacterium aquifrigidense sp. nov., isolated from a watercooling system. Int J Syst Evol Microbiol 58, 607-611.

Quan, Z.-X., Kim, K. K., Kim, M.-K., Jin, L. \& Lee, S. T. (2007). Chryseobacterium caeni sp. nov., isolated from bioreactor sludge. Int $\mathrm{J}$ Syst Evol Microbiol 57, 141-145.

Rainey, F. A., Ward-Rainey, N., Kroppenstedt, R. M. \& Stackebrandt, E. (1996). The genus Nocardiopsis represents a phylogenetically coherent 
taxon and a distinct actinomycete lineage: proposal of Nocardiopsiaceae fam. nov. Int J Syst Bacteriol 46, 1028-1096.

Saitou, N. \& Nei, M. (1987). The neighbor-joining method: a new method for reconstructing phylogenetic trees. Mol Biol Evol 4, 406425 .

Segers, P., Mannheim, W., Vancanneyt, M., De Brandt, K., Hinz, K.-H., Kersters, K. \& Vandamme, P. (1993). Riemerella anatipestifer gen. nov., comb. nov., the causative agent of septicemia anserum exsudativa, and its phylogenetic affiliation within the Flavobacterium-Cytophaga rRNA homology group. Int J Syst Bacteriol 43, 768-776.

Sierra, G. (1957). A simple method for the detection of lipolytic activity of micro-organisms and some observations on the influence of the contact between cells and fatty substrates. Antonie van Leeuwenhoek 23, 15-22.

Smibert, R. M. \& Krieg, N. R. (1994). Phenotypic characterization. In Methods for General and Molecular Bacteriology, pp. 607-654. Edited by P. Gerhardt, R. G. E. Murray, W. A. Wood \& N. R. Krieg. Washington, DC: American Society for Microbiology.

Stackebrandt, E. \& Ebers, J. (2006). Taxonomic parameters revisited: tarnished gold standards. Microbiol Today 33, 152-155.

Stolz, A., Busse, H.-J. \& Kämpfer, P. (2007). Pseudomonas knackmussii sp. nov. Int J Syst Evol Microbiol 57, 572-576.

Vandamme, P., Bernardet, J. F., Segers, P., Kersters, K. \& Holmes, B. (1994). New perspectives in the classification of the flavobacteria: description of Chryseobacterium gen. nov., Bergeyella gen. nov., and Empedobacter nom. rev. Int J Syst Bacteriol 44, 827-831.

Vaneechoutte, M., Kämpfer, P., De Baere, T., Avesani, V., Janssens, M. \& Wauters, G. (2007). Description of Chryseobacterium hominis sp. nov. to accommodate clinical isolates biochemically similar to CDC groups II-h and II-c. Int J Syst Evol Microbiol 57, 2623-2628.

Wayne, L. G., Brenner, D. J., Colwell, R. R., Grimont, P. A. D., Kandler, O., Krichevsky, M. I., Moore, L. H., Moore, W. E. C., Murray, R. G. E. \& other authors (1987). International Committee on Systematic Bacteriology. Report of the ad hoc committee on reconciliation of approaches to bacterial systematics. Int J Syst Bacteriol 37, 463-464.

Yassin, A. F. \& Hupfer, H. (2006). Williamsia deligens sp. nov., isolated from human blood. Int J Syst Evol Microbiol 56, 193-197.

Yassin, A. F., Haggenei, B., Budzikiewicz, H. \& Schaal, K. P. (1993). Fatty acid and polar lipid composition of the genus Amycolatopsis: application of fast atom bombardment mass spectrometry to structure analysis of underivatized phospholipids. Int J Syst Bacteriol 43, 414-420.

Yassin, A. F., Chen, W. M., Hupfer, H., Siering, C., Kroppenstedt, R. M., Arun, A. B., Lai, W. A., Shen, F. T., Rekha, P. D. \& Young, C. C. (2007). Lysobacter defluvii sp. nov., isolated from municipal solid waste. Int J Syst Evol Microbiol 57, 1131-1136.

Yi, H., Yoon, H. I. \& Chun, J. (2005). Sejongia antarctica gen. nov., sp. nov. and Sejongia jeonii sp. nov., isolated from the Antarctic. Int J Syst Evol Microbiol 55, 409-416. 